\title{
Thesis Writing amidst the COVID-19 Pandemic: The Case of Hospitality and Tourism Management Students of Wesleyan University Philippines
}

\author{
Gener S. Subia, Cindy O. Gaston, Jonah Faye A. Gaspar, Dulce Amor S. Padilla, \\ Maria Donna A. Valenzuela \\ College of Hospitality and Tourism Management, Wesleyan University Philippines, Cabanatuan, Philippines \\ Email: subiagener@yahoo.com
}

How to cite this paper: Subia, G. S., Gaston, C. O., Gaspar, J. F. A., Padilla, D. A. S., \& Valenzuela, M. D. A. (2022). Thesis Writing amidst the COVID-19 Pandemic: The Case of Hospitality and Tourism Management Students of Wesleyan University Philippines. Open Journal of Social Sciences, 10, 191-198. https://doi.org/10.4236/jss.2022.102013

Received: January 16, 2022

Accepted: February 15, 2022

Published: February 18, 2022

Copyright (c) 2022 by author(s) and Scientific Research Publishing Inc. This work is licensed under the Creative Commons Attribution International License (CC BY 4.0).

http://creativecommons.org/licenses/by/4.0/

\begin{abstract}
This descriptive research explored the experiences of Wesleyan University Philippines College of Hospitality and Tourism Management (CHTM) students in writing their theses during the pandemic in the academic year 2020-2021. All 145 students enrolled in the thesis writing course that responded to this study were chosen as sample respondents through the complete enumeration sampling technique. The major instrument used in this investigation was a questionnaire crafted by the researchers and validated by experts in the field. According to the findings, CHTM students believe that research is very relevant in their lives as students and future professionals. They were capable of writing their theses in a reasonably competent manner, but they were anxious and stressed when performing their research. The respondents' challenges in doing their research amidst the COVID-19 pandemic included writing the entire article, identifying appropriate respondents and getting data from them, communicating with their group mates, and consulting with their advisers. This paper has instructive implications as well as ideas for future studies along this field.
\end{abstract}

\section{Keywords}

Capability, COVID-19 Pandemic, Innovative Research, Thesis Writing, Tourism and Hospitality Management

\section{Introduction}

One of the most important aspects of every country's development is research. It 
is characterized as a methodical approach to solving problems, gathering and analyzing data to improve comprehension of a topic (Dep.Ed., 2016). For the knowledge society, the Tertiary Education Strategy outlines a clear direction for enhancing research, knowledge development, and uptake. Increased research capacities and quality, as well as more effective links with business and other external stakeholders and stronger alignment with national goals, are all promoted by the Strategy (Maharey, 2004). However, due to the COVID-19 pandemic, some university research strategies were hindered and limited. Researchers, students, and academics have all been affected by the COVID-19 pandemic (Ramos, 2021). Research and training have been disrupted as higher education institutions have curtailed in-person operations. As a result, many students have confronted new challenges (Chenneville \& Schwartz-Mette, 2020; Thompson, 2020).

Wesleyan University-Philippines, one of the autonomous universities in the country, utilized a different approach in their strategy to help their College of Hospitality and Tourism Management (CHTM) students finish their research in the midst of the pandemic. They focused on relevant and collaborative theses centered on innovative research that could address the country's problem in the hospitality industry and education during the pandemic, such as the development of vegetarian burgers and other health-related foods, marketing strategies of establishments that thrive in the time of pandemic, best teaching practices in online education, and others. These studies were pursued by student researchers, who learned the fundamentals of writing a thesis during a period when there were several constraints and policies on data collection and experimentation.

In line with these, the present study looked into the challenges CHTM students faced in writing their theses during the pandemic. Specifically, it determined their research capabilities and sentiments, and their perceptions on the relevance of research to their lives and future careers. As a result, this research has significance and substance and is different from the studies reviewed and conducted.

\section{Literature Review}

Research is concerned with finding answers or solutions to questions raised about observed issues phenomena or events in the environment through systematic and logical procedures (Nwankwo, 2013). "It is conducted all over the world to solve problems or to answer questions of significance to humanity" (Alsied \& Ibrahim, 2017: p. 144).

In tertiary education, "writing research particularly a research report is a partial fulfillment that must be met in the award of a certificate or degree in institutions of higher learning" (Kennedy, Williams, \& Asodike, 2020). However, writing a research report or thesis is one of the educational tasks that students have struggled with. "Academic writing or writing to report research is not easy because it requires adequate background knowledge, interest, motivation and hard 
work" (Alsied \& Ibrahim, 2017: p. 144). This claim has been supported by several authors. Kennedy, Williams \& Asodike (2020) found that there were moderate anxiety and fear of statistics in writing research reports of the students in Ignatius Ajuru University of Education (IAUE) Port Harcourt which is similar to the finding of Ali (2016) that their graduate students were moderately anxious about conducting research in Turkish universities. Furthermore, Libyan EFL learners have difficulty developing a research project and reporting the findings. The students found academic writing the most challenging (Alsied \& Ibrahim, 2017).

Other key challenges identified by Todd, Smith, and Bannister (2006) include students encountering intellectual challenges such as time management issues and learning how to write their thesis, choose a study topic, and then narrow it down. The toughest challenge for the students is the issue of time management. Students have a tendency to save everything until the last step. They are having trouble finishing their research on time. Wells-Moran and Dombeck (2006) assert that effective time management requires structure, commitment, and awareness, and may be used to a number of jobs in life one might choose to take on.

Challenges encountered in the Philippines among their Master of Engineering Management (M-EM) and Master of Arts in Teaching-Vocational Technological Education (MAT-VTE) student writers were the need to improve their capabilities regarding proposing a working statement, final drafting, and final organization of their research manuscripts (Subia et al., 2018). And for the teachers of a National High School in Licab, Nueva Ecija, Philippines, the main challenges they have encountered were: insufficient training and seminar on research; heavy teaching loads; lack of clear role of teachers in the school to conduct research; and busy on personal life (Abelardo et al., 2019).

\section{Methodology}

This research is a descriptive design that looked at the experiences of Wesleyan University Philippines College of Hospitality and Tourism Management students writing their theses during the pandemic in the academic year 2020-2021. According to Aggarwal (2008) as cited by Garcia et al. (2019), "descriptive research is devoted to the gathering of information about prevailing conditions or situations for description and interpretation". In this study, the researchers used the descriptive research design to describe the challenges CHTM students faced in writing their theses during the pandemic. Specifically, it determined their research capabilities and sentiments, and their perceptions on the relevance of research to their lives and future careers. 145 students enrolled in the thesis writing course that responded to this study were chosen as sample respondents using the complete enumeration sampling technique. The major instrument used in this investigation was a questionnaire created by the researchers. It was a four-point Likert scale type that measured student reactions using weighted 
means to research relevance, research writing capabilities, and research sentiments. An open-ended question was integrated at the last part of the questionnaire inquiring about the challenges the students have encountered in writing their theses during the pandemic. The questionnaire was found to be reliable with an overall Cronbach's alpha value of 0.912. The data gathering was done from September 10 to October 30, 2021. Data gathered were treated with the use of appropriate statistical tools such as frequency and weighted means.

\section{Results and Discussion}

This section presents the relevance of research based on the experiences of the respondents, their research paper writing capability, their sentiments towards research and the challenges they encountered in writing their theses.

\subsection{Relevance of Research Based on the Experiences of the Respondents}

With the use of weighted mean and Likert scale verbal description and interpretation, Table 1 shows how the respondents described the relevance of research based on their experiences. Overall, they strongly agreed that research is very relevant to their lives as students and future professionals ( $\mathrm{WM}=3.30)$.

The least rated items for the respondents were "students will be easily employed if they are good in research" $(\mathrm{WM}=3.10)$ and "Research is useful to my everyday life" (WM = 3.11). Their highest-rated items, on the other hand, were

Table 1. Relevance of research on the lives of the respondents.

\begin{tabular}{lccc}
\hline \multicolumn{1}{c}{ Items ( $\mathbf{n}=\mathbf{1 4 5})$} & WM & Verbal Description & Interpretation \\
\hline $\begin{array}{l}\text { 1) Research is related to my field of } \\
\text { specialization. }\end{array}$ & 3.20 & Moderately Agree & $\begin{array}{c}\text { Moderately } \\
\text { Relevant }\end{array}$ \\
$\begin{array}{l}\text { 2) I will benefit from my research } \\
\text { knowledge. }\end{array}$ & 3.52 & Strongly Agree & Very Relevant \\
$\begin{array}{l}\text { 3) Research is useful to my everyday } \\
\text { life. }\end{array}$ & 3.11 & Moderately Agree & $\begin{array}{c}\text { Moderately } \\
\text { Relevant }\end{array}$ \\
$\begin{array}{l}\text { 4) Research skills will help me in my } \\
\text { future profession. }\end{array}$ & 3.31 & Strongly Agree & Very Relevant \\
$\begin{array}{l}\text { 5) Research is valuable to me and to } \\
\text { every student. }\end{array}$ & 3.40 & Strongly Agree & Very Relevant \\
$\begin{array}{l}\text { 6) Research-oriented students } \\
\text { are assets of every country. }\end{array}$ & 3.41 & Strongly Agree & Very Relevant \\
$\begin{array}{l}\text { 7) Students will be easily employed } \\
\text { if they are good at research. }\end{array}$ & 3.10 & Moderately Agree & $\begin{array}{c}\text { Moderately } \\
\text { Relevant }\end{array}$ \\
$\begin{array}{l}\text { Overall Weighted Mean } \\
\text { Ond }\end{array}$ & 3.30 & Strongly Agree & Very Relevant \\
\hline
\end{tabular}

Legend: 1.00 to 1.74 Disagree/Not Relevant; 1.75 to 2.49 Slightly Agree/Slightly Relevant; 2.50 to 3.24 Moderately Agree/Moderately Relevant; 3.25 to 4.00 Strongly Agree/Very Relevant. 
"I will benefit from my research knowledge" (WM = 3.52) and "Research-oriented students are assets of every country" ( $\mathrm{WM}=3.41)$. This means that the respondents believed that their research proficiency will aid them in the future and despite their beliefs that research is not always relevant to their employment and daily life, they can contribute to the country's development. People will not be able to develop as a nation without research. They must work on their innovative ideas so that they can make their country's economy strong and push their country to a new level of success. Research can aid in the resolution of national issues and can help solve difficulties (Sharma, 2020).

\subsection{Research Paper Writing Capability of the Respondents}

With the use of weighted mean and Likert scale verbal description and interpretation, Table 2 presents the research paper writing capabilities of the respondents. An overall assessment revealed that they were moderately capable of putting down their manuscript $(\mathrm{WM}=2.91)$.

The data revealed that the respondents were capable of formatting correct layouts of tables, margins, and spacing, etc. ( $\mathrm{WM}=3.38)$ which is similar to the results of the study conducted by Subia et al. (2018) regarding "factors associated with the research paper writing capabilities of engineering management and vocational technological education freshman students". Likewise, they were also capable of "identifying sample respondents/participants" (WM = 3.36) and in "choosing their research topic" (WM = 3.32). This means that the CHTM students were knowledgeable in picking research areas and pinpointing individuals

Table 2. The capability of the respondents in writing their research paper.

\begin{tabular}{|c|c|c|}
\hline Items $(n=145)$ & WM & Highest \\
\hline 1) Choosing a research topic. & 3.32 & Capable \\
\hline 2) Picking an appropriate framework. & 2.17 & Slightly Capable \\
\hline $\begin{array}{l}\text { 3) Writing research questions/statement of the } \\
\text { problem. }\end{array}$ & 3.31 & Capable \\
\hline 4) Searching for related literature and studies. & 3.17 & Moderately Capable \\
\hline 5) Paraphrasing, quoting, and referencing. & 2.17 & Slightly Capable \\
\hline 6) Designing research instruments. & 2.13 & Slightly Capable \\
\hline 7) Designing research methodology. & 3.20 & Moderately Capable \\
\hline 8) Identifying sample respondents/participants. & 3.36 & Capable \\
\hline 9) Performing data analysis. & 2.18 & Slightly Capable \\
\hline 10) Interpreting the findings. & 3.22 & Moderately Capable \\
\hline 11) Writing conclusions and recommendations. & 3.24 & Moderately Capable \\
\hline $\begin{array}{l}\text { 12) Formatting such as correct layouts of tables, } \\
\text { margins, spacing, etc. }\end{array}$ & 3.38 & Capable \\
\hline Overall Weighted Mean & 2.91 & Moderately Capable \\
\hline
\end{tabular}


who will participate in the study. However, they need to work on their capabilities in "designing research instrument" (WM = 2.13), "paraphrasing, quoting and referencing" (WM = 2.17), and "picking an appropriate research framework" (WM = 2.17). This suggests that the "respondents were not capable of writing their questionnaire, choosing a theory where their study will be anchored, and acknowledging the work of others to avoid plagiarism" (Alvarado et al., 2016; Balian, 2010; Subia et al., 2018).

\subsection{Sentiments of the Respondents towards Research}

With the use of weighted mean and Likert scale verbal description and interpretation, Table 3 exhibits the feeling of the CHTM students towards research. The CHTM students moderately agreed that research is very complicated $(\mathrm{WM}=$ 3.19), demanding ( $\mathrm{WM}=3.02)$, and taxing ( $\mathrm{WM}=2.60)$.

They strongly agreed about their sentiments that research makes them worried too much $(\mathrm{WM}=3.42)$ and tense $(\mathrm{WM}=3.39)$. Furthermore, conducting research for them was very time-consuming $(\mathrm{WM}=3.28)$. This means that the CHTM students were unanimous in their belief that research makes people stressed and anxious. This finding is related to the results of the study conducted by Ashrafi-rizi, et al. in 2014. They have found out that "the mean level of research anxiety even among faculty members was found higher than average. So it's essential that authorities pay greater attention to the factors that cause research anxiety" (Ashrafi-rizi et al., 2014).

\subsection{Challenges Encountered by the Respondents in Writing Their Theses}

The respondents recognized the different challenges that they encountered while writing their theses. These were writing the entire manuscript, finding appropriate respondents, and gathering data from them. Communication with their

Table 3. Respondents' sentiments towards research.

\begin{tabular}{llc}
\hline \multicolumn{1}{c}{ Items $(\mathbf{n}=\mathbf{1 4 5})$} & WM & Verbal Description \\
\hline 1) Research makes me apprehensive. & 3.10 & Moderately Agree \\
2) Research is very complicated. & 3.19 & Moderately Agree \\
3) Research is demanding. & 3.02 & Moderately Agree \\
4) Research is time-consuming. & 3.28 & Strongly Agree \\
5) Research makes me worry too much. & 3.42 & Strongly Agree \\
6) Research is taxing. & 2.60 & Moderately Agree \\
7) Research makes me tense. & 3.39 & Strongly Agree \\
Overall Weighted Mean & 3.14 & Moderately Agree \\
\hline
\end{tabular}

Legend: 1.00 to 1.74 Disagree; 1.75 to 2.49 Slightly Agree; 2.50 to 3.24 Moderately Agree; 3.25 to 4.00 Strongly Agree. 
groupmates and consultation with their advisers were also identified as their difficulties due to time constraints. This result agrees with the finding of Abelardo et al. (2019), "that time-related factors took the lead concerns in doing research with a weighted mean rating of 4.14 and verbally interpreted as a Big Challenge".

\section{Conclusion}

This study found out that the CHTM students believed that research is very relevant to their lives as students and future professionals. They were moderately capable of writing their theses and felt anxious and stressed in conducting their research. Writing the entire manuscript, finding appropriate respondents and gathering data from them, communication with their group mates, and consultation with their advisers were identified as the respondents' challenges in conducting their research amidst the COVID-19 pandemic.

\section{Conflicts of Interest}

The authors declare no conflicts of interest regarding the publication of this paper.

\section{References}

Abelardo, L. J., Lomboy, M. A. A., Lopez, C. C., Balaria, F. E., \& Subia, G. S. (2019). Challenges Encountered by the National High School Teachers in Doing Action Research. International Journal of English Literature and Social Sciences (IJELS), 4, 1046-1051. http://journal-repository.com/index.php/ijels/article/view/7

Aggarwal, Y. P. (2008). Statistics of Education (2nd ed.) Sterling.

Ali, M. (2016). Research Anxiety among Turkish Graduates ELT Students. Current Issues in Education, 19, 30-38.

Alsied, S., \& Ibrahim, N. (2017). Exploring Challenges Encountered by EFL Libyan Learners in Research Teaching and Writing. IAFOR Journal of Language Learning, 3, 143-158.

Alvarado, F., Leon, M., \& Colon, A. (2016). Validation of a Questionnaire to Measure Research Skills: Experience with Engineering Students. Journal of Technology and Science Education, 6, 219-233. https://doi.org/10.3926/jotse.227

Ashrafi-Rizi, H., Sajad, M. S., Rahmani, S., Bahrami, S., \& Papi, A. (2014). The Effective Factors on Library Anxiety of Students in Isfahan University of Medical Sciences and Shiraz University of Medical Sciences. Journal of Education and Health Promotion, 3, 92. https://doi.org/10.4103/2277-9531.139667

Balian, A. (2010). Basic Research Paper Writing Skills. M.A. Linguistics, University of Warwick.

Chenneville, T., \& Schwartz-Mette, R. (2020). Ethical Considerations for Psychologists in the Time of COVID-19. American Psychologist, 75, 644-654. https://doi.org/10.1037/amp0000661

Dombeck, M., \& Wells-Moran, J. (2006). Time Management and Organization. http://www.mentalhelp.net/poc/view doc.php?type $=$ doc\&id $=9770 \& \mathrm{cn}=353$

Garcia, G., Grace, M., \& Subia, G. (2019). High School Athletes: Their Motivation, Study Habits, Self-discipline, and Academic Performance. International Journal of Physical 
Education, Sports, and Health, 6, 86-90.

Kennedy, M., Williams, E., \& Asodike, V. (2020). Anxiety in Writing Research Report among Graduate Students in Ignatius Ajuru University, Faculty of Education, Rivers State, Nigeria. Open Journal of Social Sciences, 8, 127-140.

https://doi.org/10.4236/jss.2020.811013

Maharey, S. (2004). The Role of Research in National Development. New Zealand Government.

https://www.scoop.co.nz/stories/PA0406/S00135/the-role-of-research-in-national-deve lopment.htm

Nwankwo, O. C. (2013). A Practical Guide to Research Writing for Students of Research Enterprise (3rd ed.). Port Harcourt: University of Port Harcourt Press.

Ramos, S. (2021). COVID-19's Impact Felt by Researchers: Scientists, Graduate Students Talk about Conducting Research during a Pandemic. American Psychological Association. https://www.apa.org/science/leadership/students/COVID-19-impact-researchers

Republic of the Philippines, Department of Education (2016). Adoption of the Basic Education Research Agenda.

https://www.deped.gov.ph/2016/06/10/do-39-s-2016-adoption-of-the-basic-educationresearch-agenda/

Sharma, N. (2020). Role of Research in Nation Building. NOLEGEIN Journal of Business Risk Management, 3, 9-13. https://doi.org/10.37591/njbrm.vi0.637

Subia, G. et al. (2018). Factors Associated with the Research Paper Writing Capabilities of Engineering Management and Vocational Technological Education Freshman Students. International Journal for Research \& Development in Technology, 9, 110-114. https://www.ijrdt.org/see allpaper/19/VOLUME\%20-\%209

Thompson, K. J. (2020). The Perils of Practicum in the Time of COVID-19: A Graduate Student's Perspective. Psychological Trauma: Theory, Research, Practice, and Policy, 12, S151-S152. https://doi.org/10.1037/tra0000752

Todd, M. J., Smith, K., \& Bannister, P. (2006). Supervising a Social Science Undergraduate Dissertation: Staff Experiences and Perceptions. Teaching in Higher Education, 11, 161-173. https://doi.org/10.1080/13562510500527693 